\title{
THE IMPORTANCE OF LOGISTICS AND SUPPLY CHAINS FOR PANDEMIA CONDITIONS
}

\author{
Ljiljana Stošić Mihajlović1, Svetlana Trajković \\ ${ }^{1.2}$ Academy of Applied Technical and Preschool Studies, Niš \\ stosicmihajlovicljiljana@gmail.com, cecasvtr@yahoo.com
}

\section{Professional Paper 10.5937/jouproman8-26138}

\begin{abstract}
The COVID-19 pandemic has introduced an unprecedented amount of uncertainty into the global economy as countries around the world battle growing troubles, implement broad social distancing strategies, and seek fiscal interventions to stabilize markets. What about logistics and supply chains in the market? Is there an impact of the COVID-19 virus on logisticians' obligations when securing market requirements in accordance with international business standards? Most entities have focused their attention on protecting employees, perceiving and managing risks that are threatening to business, and managing supply chain downtime due to efforts to curb the spread of virus coronas. The pervasive impact, now pandemic, on businesses and supply chains will be clearer in the coming period, while global economic recovery will depend on the impact of the affected countries to cope with the effects of the virus.
\end{abstract}

Keywords: logistics, supply chains, market

\section{Introduction}

„Overcoming physical barriers betwen buyers and sellers, when the delivery of the goods in question or of passengers when it comes to passenger traffic, is the main task of logistics, practices and skills. When it concerned modern trends clearly we can say that the future hasalready begun." 1

Already there is a serious debate in the circles of economists and, above all, businessmen regarding the estimates of

\footnotetext{
1 Stošić Mihajlović, Lj., Trajković, S. (2017). Logistics support as efficient business and transport, (JPMNT) Journal of Process Management - New Technologies, International Vol. 5, No 1, pp. 30
}

which industries will be more affected and which, once again under the influence of the pandemic, have experienced their true resurgence.

Global financial implications are likely to be felt across all industries and industries. Companies in the tourism, transport of people and goods, hospitality, logistics, automotive and aviation sectors are particularly exposed. In contrast to these parts of the economy, the least discomfort is experienced by internet service providers and information technology generally.

Also, higher business risk than usual will be exposed to entities engaged in retailing consumer goods, especially those sellers of seasonal goods. In the context of possible accompanying panic among the population, it is very ungrateful to predict the pace and dynamics of demand, which makes it difficult to optimize the procurement of trade goods.

As a classic example of a compromised business, due to the impaired supply chain, the automotive industry, where battery packs are sourced from Asia (China, South Korea) and installed in the United States, Germany, Austria, can be cited. There are an incredible number of such examples in the automotive and other parts of the globally intertwined industries. 


\section{The role and importance of logistics and the supply chain in modern economy}

A significant proportion of people make a living working in the logistics and supply chain industries. With the growth and expansion of the economic sector and the increase in population, there is a need to develop various infrastructures of the economy, which necessitates the need for an efficient and effective logistics industry to meet and facilitate needs. Of course, with the growth of the logistics industry, it will seek more human resources and provide more employment opportunities.

The steady growth of partner sectors will only increase the logistics industry as one sector cannot function optimally, especially without logistics services. The supply chain industry primarily consists of six sectors, of which the initial four relate to modes of transport such as air, road, maritime and rail. The remaining two sectors are primarily responsible for securing the shipment to the final destination through careful coordination. Such responsible segments are storage and warehousing.

Otherwise, logistics are thought to have formed when the Allied nations were to supply their troops with valuable supplies and ammunition during the Second War. In those times, supply coordination was not easy, especially given that it was more a matter of life and death. Today, just about anything and everything on the market relies on transportation and inventory management services in the industry. As every sector relies on such importance of logistics, any significant loss or damage in logistics can be felt by all other branches of the industry.
„Business Logistics and Supply Chain Management (SCM) are relatively new terms that emerged in recent years concerning to be modern terms compared to the more traditional fields of production, marketing or finance. By opening new stores globally, from which to source products, by increasing the number of retailers, wholesalers, agents and distributers in the global supply chain, as well as easing global transport, these events dramatically changed the way business looked at managing its physical operations. Therefore, this paper offers deep understanding of the main characteristics, new trends and evaluation of global logistics which referred to as global supply chain management. Global logistics plays critical role in the growth and development of world trade, and in the integration of business operations on a worldwide scale. “2

As the logistics industry is of paramount importance for an optimal working economy, many recent changes have been observed in this industry. With the continued growth and development of technology, many feasible capabilities are capable of inducing automation in the industry. It is only a matter of time before the robots will be employed in such transportation services, ensuring maximum impact without human error.

Introducing online shopping is a viable solution, when it comes to the convenience of shopping from home. Internet shopping is the dominant driving force of the logistics industry as more and more customers order products online.

\footnotetext{
2 Mateska, F. (2015). Global logistics and international channel development, (JPMNT) Journal of Process Management - New Technologies, International Vol. 3, No.1.
} 
Increasing the logistics that come from coordinating availability and delivering products from storage to doorsteps. Usually the process of transporting products from storage to delivery at the door of the consumer is usually supervised by third parties.

\section{Risk management and business impact assessment of pandemic}

Questions for assessing the impact of a virus corona on the business of businesses that management can and must ask themselves certainly include, but are not limited to, the following issues:

1) What is the impact on cash flows?

2) Does the company depend directly or indirectly on the supply of goods or services generated in the affected regions?

3) What is the possible impact of the crisis on sales and demand?

4) What happens to the company's business if employees are infected?

5) How vulnerable is the firm to unforeseen movements in market prices?

In order to manage risks adequately and at least partially mitigate them, management entities should pay particular attention to cash flow management. It is imperative that firms actively and reassess their cash needs, taking into account the various potential scenarios, as well as the potential risks to their suppliers and customers. Next, the development of appropriate, corrected, previous corrections to the activities should be undertaken.

The answers to these questions will be the first indication of how serious, in general, an entity's business impact is. Next, it will further explain the impact of the effects of the virus on the financial reporting and in what part it could, or should, reflect the amounts or / and (self) disclosures in the notes to the financial statements.

It is safe to say that retail is one of the branches most affected by the pandemic. Adaptation to new market conditions is a condition for the survival of retail chains. Even before the pandemic, the retail supply chain was unique in its complexity, necessary efficiency and high cost. Many different items require almost all modes of warehousing and transportation of goods, adequate stock, an efficient way of commissioning and a high level of software support. The width of the retail network affects the number, size and purpose of distribution centers, as well as the number and type of vehicles required for distribution. Unlike other industries, in retail chains, the supply is daily, in accordance with established routes and schedules, with the option of providing opportunities for extraordinary development and replenishment of lager for clients / retail stores.

The key to the retail supply chain could be the "dilution" of transport to the delivery of regime goods (fresh produce, meat, meat products, fruits and vegetables and the delivery of "neutral" goods. The most important difference between the two types of transport is certainly the fact that the regime goods be spread every day without losing the so-called "cold chain" until the "neutral" goods need to be transported every day.

If there is an anomaly with only one link in the retail chain servicing chain, this is reflected, more or less, on other segments by the domino effect principle, the consequences, losses in situations when you make a mistake can be big, often irreversible. 
The company's ability to prevent and suspend all the negative factors actually differentiates between successful and less successful ones, such a situation in this form and extent does not exist in logistics in other industries.

Efficient logistics is a precondition for competitiveness and survival of logistics companies - the biggest challenges come from the market.

Also, developed infrastructure is an important prerequisite for efficient operation of all participants in the transport and logistics chain. However, companies operating in this segment also face numerous challenges and problems. Domestic logistics companies are developing, foreign companies are coming, logistics centers and supporting infrastructure are being built. However, this intensive development is mostly noticed in the vicinity of Belgrade and larger cities, while much of Serbia is still underdeveloped logistically. When it comes to the transport subsystem, the situation is much worse.

Apart from road transport, which has reached the maximum of its development, other modes of transport (rail, water and air) are at a very low level of development when it comes to freight transport. It is a serious obstacle to the efficient and economical realization of international and global supply chains. For logistics providers and freight forwarding companies, this situation of transportation makes it difficult and expensive to do business in international logistics. For example, the number of containers on the Serbian market is growing significantly year by year, and Serbia does not yet have a single fully constructed and developed container terminal.
In addition to poorly developed modes of transport, logistics faces another significant problem, such as slow and complicated border procedures, trade and non-trade barriers causing significant delays and losses in the area of transport and logistics. Another problem is the regulation, which is the distribution and delivery of goods in major cities. We are currently witnessing a great deal of concern from retailers, distributors and logistics companies over the regulation of lead time due to curfew and the ban on pandemics.

All of this is to say that the development of logistics is accompanied by significant constraints and problems, but there is still intense growth in this industry. In the next post-pandemic period, it is realistic to expect this growth to be even greater and logistics and logisticians have proven to be true heroes in the Crown era. The biggest challenges for transportation and logistics companies come from the market.

New inventory-free production and sales strategies in front of logistics and supply chains are setting extremely stringent demands. Logistics is expected to deliver fewer and more frequent deliveries, with very short and strict deadlines and large "penalties". Often, all this has to be done in spatially dispersed logistics networks, and at a minimal cost. Internet sales and business digitization additionally "put pressure on logistics". Insufficient logistics infrastructure, uncoordinated regulations, underdeveloped individual modes of transport and other constraints seriously impede the effective implementation of such logistics requirements, processes and supply chains. 
All these challenges, coming from the market and from the environment, however, significant problems come from the companies themselves. Our companies, which in the period before the epidemic had a tremendous growth, failed to build the necessary internal structure, organization and systemic solutions. This primarily refers to logistics, which, unlike other functions in the company (sales, production, procurement), was most often completely neglected. This underdevelopment of logistics is today a serious constraint on the efficient development and operation of companies. Another problem in companies is the lack of cooperation and connectivity of all functions in the supply chain. It is often the cause of problems in the area of sales, procurement and production, and the consequences are manifested in the field of logistics. Partial solutions that some companies resort to will never bring greater benefits. The third problem is a serious shortage of manpower at all levels, from management to drivers and warehouse workers. Logistics is essentially a laborintensive business, relying on human resources and manpower. Serbia has long been viewed as a place of cheap but skilled labor, and this has been the main motive for some foreign companies to come to this market. Our companies also counted on cheap labor, so they did not seek and introduce any other solutions. Now that is changing significantly and it is realistic to expect that it will be a growing problem in the years to come.

It is necessary for companies to be serious about developing logistics solutions, innovating, digitizing and building systematic business support. Lack of manpower, will initiate faster development and deployment of solutions based on new technologies and automation. There is a need for serious work on solutions that will begin to replace man in the execution of his business. Such solutions are already widely applied in the world. For example, the automation of warehousing operations, where man only manages and all operations are realized by certain technologies. On the other hand, it is necessary to introduce standards, procedures and procedures of work, which most of our companies do not have now. It is necessary to put the growth and development of the company under control, that is, to fully manage all functions, including logistics. This requires concrete knowledge and skills, so it is necessary to innovate knowledge and training of employees. Investing in staff and knowledge always pays off.

\section{Logistics and process chain development perspectives: heroes from the shadow in the corona age}

Through the development and improvement of logistics, a number of effects can be achieved, which can be viewed from two key perspectives. The first is that logistics is an area where significant savings can be made, as it has been neglected for years. This was generally not the case with other functions in enterprises. Second, efficient logistics is a prerequisite for competitiveness and market survival. Only those companies with complete logistics solutions will be successful in the market. What about the world after the virus corona, who is making the right moves and whose fate will Serbia share? That is, by which time the paralysis of the economy will last, is there already a recovery somewhere and finally - where is Serbia in all this? 
It is now quite certain that the virus coronary pandemic will cause a global recession in 2020, which may be worse than that seen during the global financial crisis of 2008-2009, but global economic output should recover in 2021. After all, the IMF warned, and 80 countries have already asked for help from that lender.

While managing an immediate health crisis is vital and essential for economic stability, experts have already begun assessing what recovery may look like after the virus has withdrawn and which countries may be the first to breathe.

Denmark and Norway are at the top of the countries with the most resilient economies, the countries that will recover the fastest after the global pandemic of the coronary virus. The list of economic systems resilience ranks the resilience of the business environment in 130 countries based on factors such as political stability, corporate governance, environmental risk, supply chain logistics and transparency.

The ten countries with the highest capacity for rapid recovery are Norway, Denmark, Switzerland, Germany, Finland, Sweden, Luxembourg, Austria, Central American countries and the United Kingdom. Of the countries in the region, Croatia ranks 37th, Slovenia at 42 , Serbia at 63 , and $\mathrm{BiH}$ at 70 . Denmark, which scores high on supply chains, stands out as an example of economic capacity. She responded swiftly when it came to enacting social distancing for the spread of the virus. Measures such as reimbursement of $90 \%$ of the hourly wage and $75 \%$ of the crisis-affected fulltime worker were hailed in the rest of the world as an example because it's essentially about "freezing" the economy until the "storm" passes. New Zealand, Singapore, 58 which is said to be high on the list because of its strong economy, low political risk, strong infrastructure and low corruption, also ranked 21st in the list. Interestingly, Rwanda also boasts. Residents there believe that the situation will be resolved in a better way than in neighboring countries. They attribute this to the recent improvement in corporate governance.

The merits of health care professionals in the current situation in which we are battling the corona virus are immeasurable. But in addition to them, there are more shadow heroes who, in these extraordinary circumstances, make the system work. Employees in manufacturing, retailing, distribution, transport and logistics are committed to working hard every day, in the face of new challenges, to make products accessible to our citizens on storefronts.

Numerous companies in Serbia are a good example of a successful company being given special care by its employees. In addition to working hours and all the measures that companies take to keep their employees and customers safe in stores, there are also earnings bonuses for all salespeople and logisticians. While goods are ordered, received and commissioned at logistics centers, and taken over, displayed and cashed in stores, the mutual support and cooperation of these employees is not lacking. This is visible to consumers as the true heroes of today, in the age of the Crown, are workers who are full of solidarity and patience every day, and it should be noted that work on Sundays when shops open their doors early in the morning for citizens over 65 years old. 


\section{Conclusion}

Infection caused by the new Crown Virus (COVID-19) is spreading around the world. While countries are taking action to counter it, companies must make important operational decisions, and it is undoubted that its devastating impact will have consequences on the world economy. According to the official position, three economic sectors are most vulnerable to COVID-19 in Serbia. These are tourism, transport and logistics. However, the prohibition of crossing borders to prevent the spread of the virus - for trucks does not apply. All countries have declared transportation necessary and allowed drivers to cross the border with limited residence and contact only for the purpose of delivery and pickup. However, the columns at the borders still extended relative to normal, and therefore the speed of transport. In a time of pandemic that has engulfed the entire world, the real heroes are the people who work in logistics and operations. To them, all the credit goes to the fact that, for example, in Serbia, the excellent supply of the market with all the necessary goods and services enables the functioning of both economic entities, which, under the changed conditions, seek to maintain a certain degree of capacity utilization and of the population.

\section{References}

[1] Stošić Mihajlović Lj., (2017). Poslovna logistika, VŠPSS, Vranje.

[2] http://logistikaitransport.com/transport-idistribucija/prilagodavanje-na-novu-stvarnost-umaloprodaji/

[3]

https://www.ekapija.com/news/2700620/efikasnalogistika-preduslov-za-konkurentnost-i-opstanaklogistickih-kompanija-najveci-izazovi-dolaze

[4] Bjelić, V.,Šta će biti sa svetom posle korona virusa, ko vuče prave poteze i čiju sudbinu će da deli Srbija? Dostupno n:https://biznis.telegraf.rs/infobiz/3169460-sta-ce-biti-sa-svetom-posle-koronavirusa-ko-vuce-prave-poteze-i-ciju-sudbinu-ce-dadeli-

srbija?utm_source=nove_povezane_vesti\&utm_med ium=preporucene\&utm_campaign=nove_povezane_ vesti\&utm_content=horizontalno_kraj https://www.fmglobal.com

[5] Mateska, F. (2015). Global logistics and international channel development, (JPMNT) Journal of Process Management - New Technologies, International Vol. 3, No.1.

[6] Stošić Mihajlović, Lj., Trajković, S. (2017). Logistics support as efficient business and transport, (JPMNT) Journal of Process Management - New Technologies, International Vol. 5, No 1, pp. 30 